\title{
The Use of the Internet and Web 2.0 Tools among EFL Instructors
}

\author{
Ingilizce Okutmanlarının Web 2.0 Araçları ve İnternet Kullanımları
}

\begin{abstract}
Ahmet Gazi ÖZEL* Arda ARIKAN**

Abstract: In language learning and teaching, the Internet and Web 2.0 tools present resources and opportunities for both students and teachers mainly because of these tools' communicative potentials. The purpose of this study was to investigate the use of the Internet and Web 2.0 tools among EFL instructors and examine their perceptions in respect to the use of the Internet and Web 2.0 tools for teaching purposes. Data was gathered via a questionnaire developed in cognisance of the related literature and of expert opinion. The questionnaire was distributed on-line to EFL instructors $(n=112)$ at various universities in Turkey. The resulting data was analyzed using SPSS 20.0 and reported employing descriptive statistics, frequencies, means, percentages and standard deviations. The results showed that EFL instructors had positive attitudes towards the use of the Internet and Web 2.0 tools. Although they had positive thoughts concerning Web 2.0 tools, they were not using these tools in a sufficient manner in their teaching and were not pleased with the degree of opportunity their schools gave them to learn about the Internet.
\end{abstract}

Keywords: Technology, The Internet, Web 2.0 Tools, Instructors

Öz: Dil öğreniminde ve öğretiminde, internet ve Web 2.0 araçları hem öğrenciler hem de öğretmenler için muazzam kaynaklar ve firsatlar sunar. Bu bağlamda, bu çalışmanın amacı İngilizce okutmanlarının internet ve Web 2.0 araçları kullanımlarını araştırmak ve onların öğretim amaçları için internet ve Web 2.0 araçları kullanımına karşı olan tutumlarını incelemektir. Veri toplamak için araç olarak ilgili literatürden ve uzmanların görüşlerinden yararlanılarak bir anket geliştirilmiştir. Anket Türkiye'deki farklı üniversitelerde çalışan okutmanlara $(\mathrm{n}=112)$ online olarak gönderilmiştir. Elde edilen veriler SPSS 20.0 programı kullanılarak analiz edilmiştir ve betimsel istatistik, frekanslar, ortalama, yüzdeler ve standart sapma kullanılarak rapor edilmiştir. Çalışmanın sonuçlarına göre İngilizce okutmanlarının internet ve Web 2.0 araçları kullanımına karşı pozitif tutumlarının olduğu sonucuna varılmıştır. Okutmanların Web 2.0 araçlarına yönelik pozitif tutumları olmasına karşın bu araçları kendi öğretimlerinde yeterince kullanmadıkları ve internet hakkında bilgi edinmek için kendi çalıştıkları okulların onlara sağladıkları imkanlardan memnun olmadıkları sonucu ortaya çıkmıştır.

Anahtar sözcükler: Teknoloji, İnternet, Web 2.0 Araçları

\footnotetext{
* Instructor, Akdeniz University, School of Foreign Languages, Antalya. a.gaziozel@gmail.com

** Assoc. Prof. Dr., Akdeniz University, Faculty of Letters, Department of English Language and Literature, Antalya. ardaari@gmail.com

This article reports the MA thesis submitted to Akdeniz University's Institute of Educational Sciences.
} 


\section{Introduction}

Online learning environments supply learners with opportunities to develop their language skills in a way that supports a student-centered approach that can be established in all fields and at all levels of education (Arikan 2008a; Arikan 2008b). In the field of education, numerous innovative tools and approaches have emerged in a way that integrates technology into the learning and teaching processes (Kassim \& Ali 2007). Influential Internet tools provide students with opportunities that lead them to authentic social communication and meaningful input (Rashtchi \& Hajihassani 2010). Today, the main aim of foreign language teaching is to provide a learner-centered environment where learners use the target language to interact with others while simultaneously expanding their own communicative competence (Lee 2005). Hence, online learning environments help the students to control their own learning according to their needs (Caner 2009).

The use of Internet-based resources in educational environments has been steadily increasing over the years, mainly due to their availability as they can generally be accessed free of charge (Motteram \& Sharma 2009). Similarly, Dovedan, Seljan, and Vučković $(2002,75)$ discuss some of the following advantages of using the Internet for educational purposes:

1. twenty-four hour access to materials;

2. data that can be easily changed, edited, added, or exchanged and compared among different users;

3. communication happening outside the existing place and time;

4. the ease of adjusting exercises and drills to different knowledge levels;

5. the development of new and existing technology skills usage;

6. extending skills for individual research and team work;

7. achievement of social awareness.

\section{Web 1.0 vs. Web 2.0 Tools}

Web 1.0 refers to those static web pages with hyperlinks to other pages and resources. As Web 1.0 sites are static, personal and not interactive, they are generally termed the readable web which does not permit the readers' spoken or written additions. Among Web 1.0 tools, personal web sites and online encyclopedias are the most common popular examples that have been used all around the world. Unlike Web 2.0 tools which allow the users to create and to share information, Web 1.0 tools are known to be limited because of their passivity in communication (Motteram \& Sharma 2009) while Web 2.0 tools provide authentic and collaborative learning environments through enabling socialization, collaboration, creativity, authenticity and sharing (Peachey 2009).

The introduction of the Internet in language education began with Web 1.0 tools, and eventually progressed to Web 2.0 tools. English as a Foreign Language (EFL) research has shown that blogs, wikis, and podcasts are the most frequently used Web 2.0 tools today (Kartal \& Arikan 2011). Due to the current widespread use of social media platforms such as Facebook and Twitter, it is also necessary to consider the impact of social networking sites. Web 2.0 tools not only provide authenticity and collaboration but they also assist in teaching language skills as they give students control over their learning. As Dawley $(2007,208)$ states, "blogs and wikis are being used by many instructors to support the writing process, assist reflection in learning, provide student empowerment, and to promote the idea of students as experts in their own learning process". A secondary advantage of using blogs in the language learning process is that students can incorporate written texts, graphics, audio files, videos and links to this 
platform (Hernández-Ramos 2004), which in turn enables them to practice not only their writing but also their reading and listening skills. Podcasts, in turn, are helpful tools in developing listening skills (Kavaliauskiene \& Anusiene 2009). Kavaliauskiene and Anusiene (2009) state that students can listen to a podcast and read its script at the same time, and then may record a response to the topic and submit this, and a written journal to their teacher. The teacher then can listen to the recording and provide feedback. By using podcasts in this way, it is possible to improve fluency in students' listening, reading, speaking, pronunciation and vocabulary (Kavaliauskiene \& Anusiene 2009), making this truly a multi-purpose learning platform. When engaging in an open interactive dialogue, it is not possible to separate these distinct language skills, as they are all employed simultaneously. Therefore, Web 2.0 tools such as blogs and podcasts can be used in the integration of language skills in order to increase and enhance authentic communication.

The prevalence of technology in the classroom has contributed to a shift in traditional teacher roles within learning environments. In constructivism based instruction, students are at the center of the learning environment while the instructors act as a guide or a facilitator (Allen 2008). The habits of the traditional classroom must be discarded as teachers undertake the difficult task of showing students how to attain knowledge and personal enlightenment versus merely absorbing it. Students today are intensely interested in technology mainly because they are born into this Internet culture. Prensky $(2001,1)$ refers to them as "digital natives" and states that "they are all 'native speakers' of the digital language of computers, video games, and the Internet". Hence, it is imperative for teachers to be able to speak the same language with these 'digital natives'. Each generation brings its own technological advancements and it is imperative for teachers to expand their knowledge and skills accordingly so that they can keep abreast of modern trends such as 'podcasting' (Motteram \& Sharma 2009).

Previous research on Web 2.0 tools shows that Web 2.0 tools are not popular among EFL learners (see Table 1). Studies conducted with future teachers have shown that the use of the Internet and Web 2.0 tools is not common, but little is known concerning to what extent EFL instructors are aware of the existence of these tools. Hence, much research is needed to investigate the use of the Internet and Web 2.0 tools amongst EFL instructors. Therefore the main purpose of the study is to explore the use of the Internet and Web 2.0 tools among EFL instructors. Corresponding with the aim of the study, answers to the following research questions were requested:

1. How often do EFL instructors use the Internet and Web 2.0 tools?

2. What is the level of EFL instructors' proficiency in computer and the Internet use?

3. What are the EFL instructors' perceptions towards the use of the Internet and Web 2.0 tools in language instruction?

Table 1. Related studies in the field of English language teaching

\begin{tabular}{|c|c|l|}
\hline Studies & Participants & \multicolumn{1}{c|}{ Findings } \\
\hline $\begin{array}{c}\text { Cahyani and } \\
\text { Cahyono (2012) }\end{array}$ & Teachers & $\begin{array}{l}\text { The types of technology used by the teachers, ranking from the highest } \\
\text { frequency, are notebooks/computers, tape recorders, multimedia and } \\
\text { websites. } \\
\text { Teachers have positive attitudes towards technology use in the classroom. }\end{array}$ \\
\hline $\begin{array}{c}\text { Cephe and } \\
\text { Balçıanlı (2012) }\end{array}$ & $\begin{array}{c}\text { Prospective } \\
\text { teachers }\end{array}$ & $\begin{array}{l}\text { Prospective teachers have positive feelings about the use of Web 2.0 } \\
\text { tools. }\end{array}$ \\
\hline $\begin{array}{c}\text { Gilakjani and } \\
\text { Leong (2012) }\end{array}$ & Teachers & $\begin{array}{l}\text { Introducing technology resources does not assure teachers' use of these } \\
\text { resources in language teaching. } \\
\text { The importance of training for teachers, and their need for explanation, } \\
\text { guidance and assistance are emphasized. }\end{array}$ \\
\hline
\end{tabular}




\begin{tabular}{|c|c|c|}
\hline $\begin{array}{c}\text { Khassawneh } \\
\text { (2012) }\end{array}$ & Teachers & $\begin{array}{l}\text { Most of the teachers had positive attitudes and a willingness to use the } \\
\text { Internet, but their integration of the Internet into their teaching was very } \\
\text { inadequate. }\end{array}$ \\
\hline $\begin{array}{l}\text { Kartal and Arikan } \\
\qquad(2011)\end{array}$ & $\begin{array}{l}\text { Prospective } \\
\text { teachers }\end{array}$ & $\begin{array}{l}\text { While social networking, online music, and e-mails are the most widely } \\
\text { used tools by prospective teachers, podcasts and blogs are the least used. }\end{array}$ \\
\hline $\begin{array}{c}\text { Rahimi and } \\
\text { Yadollahi (2011) }\end{array}$ & Teachers & $\begin{array}{l}\text { Teachers used digital portable devices more than computer or network } \\
\text { tools in the classroom and they used technology mostly in the teaching of } \\
\text { oral skills. } \\
\text { ICT use decreases with age and teaching experience and younger teachers } \\
\text { integrate technology into their teaching more than older teachers. }\end{array}$ \\
\hline Şahin-Kızıl (2011) & Teachers & $\begin{array}{l}\text { The most extensively used ICT tools are the gradebook, the Internet, } \\
\text { software for repetitive practice, processing text, interactive exercises and } \\
\text { PowerPoint Presentations. } \\
\text { Teachers had positive attitudes towards the use of ICT for educational } \\
\text { purposes. }\end{array}$ \\
\hline $\begin{array}{c}\text { Solmaz and } \\
\text { Bekleyen (2011) }\end{array}$ & Teachers & $\begin{array}{l}\text { Teachers mostly followed resources from websites, forums and social } \\
\text { networks, dictionaries, magazines and blogs respectively. }\end{array}$ \\
\hline Dogoriti (2010) & Teachers & $\begin{array}{l}\text { E-mail, chatting software, blogs and online resources are found to be } \\
\text { rarely used by EFL teachers } \\
\text { Younger teachers are more likely to use ICT applications. } \\
\text { Most teachers have a positive attitude towards the use of ICT in foreign } \\
\text { language teaching and learning. }\end{array}$ \\
\hline Horzum (2010) & Teachers & $\begin{array}{l}\text { Most teachers were aware of Facebook, MSN and VSS but blogs and } \\
\text { podcasts were not widely used in the classroom. }\end{array}$ \\
\hline Saklavcı (2010) & Teachers & $\begin{array}{l}\text { Teachers very frequently use the Internet but mainly not for instructional } \\
\text { purposes. } \\
\text { Although teachers had positive perceptions of the Internet, they do not } \\
\text { use it for their lessons. }\end{array}$ \\
\hline Külekçi (2009) & $\begin{array}{l}\text { Prospective } \\
\text { teachers }\end{array}$ & $\begin{array}{l}\text { Although prospective teachers have positive opinions towards the use of } \\
\text { the Internet, their computer skills are inadequate. }\end{array}$ \\
\hline $\begin{array}{c}\text { Usluel, Mazman } \\
\text { and Arikan (2009) }\end{array}$ & $\begin{array}{l}\text { Prospective } \\
\text { teachers }\end{array}$ & $\begin{array}{l}\text { Podcasts are the least popular tools used by student teachers while wikis } \\
\text { are the most popular. } \\
\text { In general, Web } 2.0 \text { tools are not popular in student teachers' lives. }\end{array}$ \\
\hline Arikan (2008) & $\begin{array}{l}\text { Prospective } \\
\text { teachers }\end{array}$ & $\begin{array}{l}\text { Through the Internet, prospective teachers reported that their reading } \\
\text { skills improved the most ( } 88.9 \%) \text { and their speaking skills the least } \\
(44.6 \%) \text {. } \\
\text { Prospective EFL teachers may not have realized the potential of the } \\
\text { Internet for the improvement of their oral skills. }\end{array}$ \\
\hline $\begin{array}{l}\text { Shin and Son } \\
\text { (2007) }\end{array}$ & Teachers & $\begin{array}{l}\text { Most teachers use the Internet for their teaching purposes, and their aim } \\
\text { was mostly to prepare teaching materials. } \\
\text { Web surfing activities were found to be used most frequently. } \\
\text { Teachers agreed on the effectiveness of the Internet in EFL teaching. }\end{array}$ \\
\hline Al-Asmari (2005) & Teachers & $\begin{array}{l}\text { Teachers used the Internet for more personal than instructional purposes. } \\
\text { They used mainstream Internet services such as e-mailing and the World } \\
\text { Wide Web. } \\
\text { They had positive perceptions towards the use of the Internet as a } \\
\text { pedagogical tool. }\end{array}$ \\
\hline $\begin{array}{l}\text { Al-Mekhlafi } \\
\text { (2004) }\end{array}$ & Teachers & $\begin{array}{l}\text { Although they show positive attitudes, EFL teachers are not currently } \\
\text { using the Internet while teaching. }\end{array}$ \\
\hline Arkın (2003) & Teachers & $\begin{array}{l}\text { Although most teachers believe in the usefulness of technological } \\
\text { resources, familiarizing the teachers with these resources does not } \\
\text { guarantee their use in language instruction. }\end{array}$ \\
\hline
\end{tabular}

In accordance with the above review of the related literature, this study aimed to determine the perceptions of EFL instructors towards the use of the Internet and specific Web 2.0 tools in their learning and teaching. More specifically, the instructors' personal characteristics, their knowledge and use of the Internet and Web 2.0 tools, proficiency in using the computer and the Internet 
applications and their perceptions of the Internet and Web 2.0 tools for teaching purposes are studied.

\section{Methodology}

For the purposes of the study, a quantitative approach was followed. A descriptive research design was utilized to achieve the objectives of the study. Descriptive statistical techniques (frequencies, percentages, means, and standard deviations) were used to determine the level of the Internet and Web 2.0 tools used by the language instructors.

\section{Participants}

The participants were selected in accordance with a convenience sampling procedure. Participants were reached either by e-mail or through contacting them using their Facebook profiles. All of the respondents were working at Schools of Foreign Languages at different universities. Almost $72 \%$ percent $(n=80)$ of the participants were females which is to be expected within the context of university-level schools in Turkey.

\section{Data Gathering Instrument}

In order to collect data from the instructors concerning their attitudes towards the use of the Internet and Web 2.0 tools, a questionnaire was employed. The questionnaire was adapted with minor changes by reviewing the related studies in the field (Al-Asmari 2005; Usluel, Mazman \& Arikan 2009). By reviewing questionnaires in the related literature and writing new items the pool of questions were prepared. Then, the items were reviewed and categorized according to the purposes of the study. After this phase, the questionnaire was examined by four experts working as Assistant Professors ( $n=2)$ and Associate Professors $(n=2)$ of English as a Foreign Language. It was a self-administered questionnaire and consisted of three parts. The first part was designed to determine the frequency of Internet and Web 2.0 tools use in a week amongst the participants. The next section aimed to learn about the participants' proficiency in using some of the computer and the Internet applications. Finally, the third part aimed to determine the participants' perceptions of the use of the Internet and of Web 2.0 tools for teaching purposes.

For the validity of the survey questions, the above mentioned four experts assessed the clarity of each of the items. Considering the experts' opinions and feedback, some of the items were improved and the necessary editing was done. The reliability of the survey used in this study was calculated using Cronbach's alpha value via SPSS 20.0 and it was found to be .933 which is considered acceptable and highly reliable in similar studies. Participants responded to eight Likert-type items concerning their use of Web 1.0 and Web 2.0 tools. A mean score based on a 5-point response scale ranging from 1 (I don't really use) to 5 (21+ hours) was used to represent the level of the use of the Internet and Web 2.0 tools by EFL instructors.

\section{Data Analysis}

The survey data were analyzed using SPSS 20.0 and reported employing appropriate measures and procedures. To do that, frequencies and percentages are calculated.

\section{Findings}

\section{The Internet and Web 2.0 Tools Use among EFL Instructors}

Table 2 shows the percentages, frequencies and mean scores related to EFL instructors' weekly use of Web 1.0 and Web 2.0 tools. 
Table 2. EFL instructors' weekly use of Web 1.0 and Web 2.0 tools

\begin{tabular}{|c|c|c|c|c|c|c|c|c|c|c|c|c|}
\hline & \multicolumn{2}{|c|}{$\begin{array}{l}\text { I don't } \\
\text { really use }\end{array}$} & \multicolumn{2}{|c|}{$\begin{array}{c}(1-5 \\
\text { hours })\end{array}$} & \multicolumn{2}{|c|}{$\begin{array}{l}(6-10 \\
\text { hours) }\end{array}$} & \multicolumn{2}{|c|}{$\begin{array}{l}(11-20 \\
\text { hours })\end{array}$} & \multicolumn{2}{|c|}{$\begin{array}{l}(21+ \\
\text { hours) }\end{array}$} & & \\
\hline & $\mathrm{f}$ & $\%$ & $\mathrm{f}$ & $\%$ & $\mathrm{f}$ & $\%$ & $\mathrm{f}$ & $\%$ & $\mathrm{f}$ & $\%$ & Mean & S. D. \\
\hline Electronic-mail & 0 & 0 & 35 & 31.3 & 28 & 25 & 17 & 15.2 & 32 & 28.6 & 3.41 & 1.204 \\
\hline $\begin{array}{l}\text { Newsgroups and } \\
\text { forums }\end{array}$ & 29 & 25.9 & 49 & 43.8 & 15 & 13.4 & 9 & 8 & 10 & 8.9 & 2.30 & 1.199 \\
\hline Search Engines & 0 & 0 & 32 & 28.6 & 27 & 24.1 & 22 & 19.6 & 31 & 27.7 & 3.46 & 1.177 \\
\hline $\begin{array}{c}\text { Instant } \\
\text { Messaging }\end{array}$ & 45 & 40.2 & 36 & 32.1 & 4 & 3.6 & 12 & 10.7 & 15 & 13.4 & 2.25 & 1.423 \\
\hline Blogs & 46 & 41.1 & 38 & 33.9 & 14 & 12.5 & 5 & 4.5 & 9 & 8 & 2.04 & 1.203 \\
\hline Podcasts & 64 & 57.1 & 31 & 27.7 & 9 & 8 & 4 & 3.6 & 4 & 3.6 & 1.68 & 1.013 \\
\hline Wikis & 35 & 31.3 & 42 & 37.5 & 15 & 13.4 & 9 & 8 & 11 & 9.8 & 2.27 & 1.260 \\
\hline $\begin{array}{c}\text { Social Network } \\
\text { Sites }\end{array}$ & 7 & 6.3 & 36 & 32.1 & 20 & 17.9 & 16 & 14.3 & 33 & 29.5 & 3.28 & 1.351 \\
\hline
\end{tabular}

Considering the mean scores, it was found that search engines (3.46), e-mails (3.41) and social network sites (3.28) were the most frequently used tools amongst EFL instructors. On the other hand, the least frequently used tool was the podcast (1.68) which is followed by blogs (2.04). These results suggest that Web 2.0 tools are not popular when compared with Web 1.0 tools.

\section{The Level of EFL Instructors' Proficiency in Computer and the Internet Use}

The EFL instructors were asked to specify their proficiency in using selected computer and the Internet applications. Participants responded to items on a 5-point Likert-type scale ranging from 5 (Very Knowledgeable) to 1 (Don't Know It). The overall mean for the instructors' proficiency in computer and the Internet applications was 3.77, which alludes to a rather high level of proficiency.

Table 3. Computer and the Internet Proficiency

\begin{tabular}{|c|c|c|c|c|c|c|c|c|c|c|c|c|}
\hline & \multicolumn{2}{|c|}{$\begin{array}{c}\text { Don't know } \\
\text { it }\end{array}$} & \multicolumn{2}{|c|}{$\begin{array}{c}\text { Not } \\
\text { Knowledge- } \\
\text { able }\end{array}$} & \multicolumn{2}{|c|}{$\begin{array}{l}\text { Know it but } \\
\text { not using }\end{array}$} & \multicolumn{2}{|c|}{$\begin{array}{l}\text { Knowledge- } \\
\text { able }\end{array}$} & \multicolumn{2}{|c|}{$\begin{array}{c}\text { Very } \\
\text { Knowledge- } \\
\text { able }\end{array}$} & \multirow[b]{2}{*}{ Mean } & \multirow[b]{2}{*}{ S. D. } \\
\hline & $\mathrm{f}$ & $\%$ & $\mathrm{f}$ & $\%$ & $\mathrm{f}$ & $\%$ & $\mathrm{~F}$ & $\%$ & $\mathrm{f}$ & $\%$ & & \\
\hline Word processing & 0 & 0 & 0 & 0 & 2 & 1.8 & 59 & 52.7 & 51 & 45.5 & 4.43 & .533 \\
\hline $\begin{array}{l}\text { Spreadsheets } \\
\text { (e.g. Excel) }\end{array}$ & 1 & 0.9 & 24 & 21.4 & 19 & 17 & 51 & 45.5 & 17 & 15.2 & 3.52 & 1.021 \\
\hline Graphics & 5 & 4.5 & 29 & 25.9 & 27 & 24.1 & 42 & 37.5 & 9 & 8 & 3.18 & 1.052 \\
\hline $\begin{array}{c}\text { Presentation } \\
\text { software }\end{array}$ & 0 & 0 & 5 & 4.5 & 13 & 11.6 & 50 & 44.6 & 44 & 39.3 & 4.18 & .811 \\
\hline Podcasts & 7 & 6.3 & 34 & 30.4 & 35 & 31.3 & 25 & 22.3 & 11 & 9.8 & 2.99 & 1.086 \\
\hline Wikis & 3 & 2.7 & 22 & 19.6 & 36 & 32.1 & 39 & 34.8 & 12 & 10.7 & 3.31 & .995 \\
\hline $\begin{array}{l}\text { Receive and send e- } \\
\text { mail (with } \\
\text { attachments) }\end{array}$ & 0 & 0 & 0 & 0 & 0 & 0 & 23 & 20.5 & 89 & 79.5 & 4.79 & .405 \\
\hline Create a web page & 25 & 22.3 & 44 & 39.3 & 20 & 17.9 & 12 & 10.7 & 11 & 9.8 & 2.46 & 1.229 \\
\hline Use search engines & 0 & 0 & 1 & 0.9 & 0 & 0 & 23 & 20.5 & 88 & 78.6 & 4.76 & .483 \\
\hline
\end{tabular}




\begin{tabular}{|c|c|c|c|c|c|c|c|c|c|c|c|c|}
\hline On-line chat rooms & 3 & 2.7 & 13 & 11.6 & 52 & 46.4 & 14 & 12.5 & 30 & 26.8 & 3.49 & 1.090 \\
\hline Instant messaging & 1 & 0.9 & 2 & 1.8 & 21 & 18.8 & 40 & 35.7 & 48 & 42.9 & 4.17 & .861 \\
\hline $\begin{array}{c}\text { On-line forums, } \\
\text { blogs }\end{array}$ & 2 & 1.8 & 6 & 5.4 & 44 & 39.3 & 39 & 34.8 & 21 & 18.8 & 3.63 & .910 \\
\hline $\begin{array}{c}\text { Download } \\
\text { films/music and } \\
\text { save them for future } \\
\text { use }\end{array}$ & 1 & 0.9 & 4 & 3.6 & 20 & 17.9 & 39 & 34.8 & 48 & 42.9 & 4.15 & .902 \\
\hline \begin{tabular}{c} 
TOTAL \\
\hline
\end{tabular} & & & & & & & & & 3.77 & \\
\hline
\end{tabular}

As shown in Table 3, the highest level of ability was in the domain of "receiving and sending email" (4.79). All of the participants indicated their proficiency as "Knowledgeable" (20.5\%) or "Very Knowledgeable" (79.5\%). With a 4.76 mean score, using search engines follows, 99.1\% of the participants reported their level as "Knowledgeable" (20.5\%) or "Very Knowledgeable" (78.6\%), and only one instructor (0.9\%) identified himself/herself as "Not Knowledgeable". Word processing (98.2\% "knowledgeable" or "very knowledgeable"), presentation software (83.9\% "knowledgeable" or "very knowledgeable"), instant messaging (78.6\% "knowledgeable" or "very knowledgeable"), and downloading films/music and saving them for the future $(77.7 \%$ "knowledgeable" or "very knowledgeable") were the applications with which the participants had a high level of proficiency.

Another lower level of proficiency was found to be in creating a web page (2.46). Twentytwo point three percent of the participants indicated that they don't know how to create a web page. Fifty-seven point two percent responded as either "Not knowledgeable" (39.3\%) or "Know it but not using" (17.9\%).

\section{EFL Instructors' Perceptions of the Use for Teaching Purposes of the Internet and Web 2.0 Tools}

EFL instructors were asked to respond to 33 items concerning their perceptions of the use for teaching purposes of the Internet and Web 2.0 tools. They reported their level of agreement/ disagreement on a 5-point Likert-type scale ranging from 5 (Strongly Agree) to 1 (Strongly Disagree). As shown in Table 4, the summated mean of the 33 items measuring the instructors' attitudes towards the use of the Internet and Web 2.0 tools was 3.82. This indicates that on the whole, participants had a positive perception of the Internet and Web 2.0 tools.

Table 4. Mean scores of EFL instructors' perceptions of the Internet and Web 2.0 tools

\begin{tabular}{|l|l|l|l|l|}
\hline $\mathrm{N}$ & Minimum & Maximum & Mean & Std. Deviation \\
\hline 112 & 2.61 & 4.79 & 3.82 & .452 \\
\hline
\end{tabular}

\section{Results Related to the Internet Use}

The participants' responses to the items aimed to establish their attitudes towards the Internet showed that they had a high level of positive agreement. As shown in Table 5, over $90 \%$ of the instructors reported a high level of agreement to the questionnaire items, 2, 3, 8, 9, 10 and 18. Not only were the attitudes of the instructors towards the Internet high, but $87.5 \%$ also agreed with the item "I'm using the Internet to teach". For the questionnaire' first item, "use of the Internet increases my social prestige", 53.6\% agreed, but 38.4\% were unsure and 8\% were in disagreement. In the questionnaire' sixth item, participants were asked whether their school provided opportunities for them to teach with the Internet, and 53.6\% said "yes", 21.4\% were unsure, and 25\% said "no". The questionnaire' fifth item aimed to discover whether the 
participants' schools provided opportunities for them to learn about the Internet, and 33.9\% said "yes", $37.5 \%$ were unsure, and $28.6 \%$ said "no". From these results, it can be concluded that although instructors have positive attitudes towards the Internet and they use it in their classes, they are not satisfied with the opportunities that they are offered to learn about the Internet. This may be interpreted as a desire for more training in respect to the Internet. Ninety-two percent of the participants also agreed with item number 8 "EFL teachers should be educated/trained to use the Internet for instructional purposes".

Table 5. Results relating to Internet use

\begin{tabular}{|c|c|c|c|c|}
\hline & $\begin{array}{c}\text { Strongly } \\
\text { Disagree } \\
\text { and } \\
\text { Disagree }\end{array}$ & Neutral & $\begin{array}{c}\text { Strongly } \\
\text { Agree and } \\
\text { Agree }\end{array}$ & \\
\hline & \multicolumn{3}{|c|}{$\%$} & Mean \\
\hline 1. Use of the Internet increases my social prestige. & 8 & 38.4 & 53.6 & 3,6339 \\
\hline $\begin{array}{l}\text { 2. Use of the Internet increases my performance in } \\
\text { my job. }\end{array}$ & 1.8 & 3.6 & 94.6 & 4,4107 \\
\hline 3. The Internet is easy to use. & 0 & 2.7 & 97.3 & 4,5625 \\
\hline $\begin{array}{l}\text { 5. My school provides opportunities for me to learn } \\
\text { about the Internet. }\end{array}$ & 28.6 & 37.5 & 33.9 & 3,1518 \\
\hline $\begin{array}{l}\text { 6. My school provides opportunities for me to teach } \\
\text { with the Internet. }\end{array}$ & 25 & 21.4 & 53.6 & 3,4821 \\
\hline $\begin{array}{l}\text { 8. EFL teachers should be educated/trained to use the } \\
\text { Internet for instructional purposes. }\end{array}$ & 1.8 & 6.3 & 92 & 4,5089 \\
\hline 9. Using the Internet saves time and effort. & 2.7 & 4.5 & 92.9 & 4,5268 \\
\hline $\begin{array}{l}\text { 10. The Internet offers opportunities for learning new } \\
\text { teaching techniques. }\end{array}$ & 0.9 & 3.6 & 95.5 & 4,5446 \\
\hline 18. Internet use increases my students’ motivation. & 0 & 2.7 & 97.3 & 4,4196 \\
\hline 21. I’m using the Internet in my teaching. & 5.4 & 7.1 & 87.5 & 4,1875 \\
\hline
\end{tabular}

\section{Results Related to Language Skills}

Participants were asked about teaching language skills, vocabulary, grammar, and the target culture through using the Internet. Their agreement on finding the resources for the teaching of vocabulary had the highest score $(82.1 \%)$. In descending percentage they also claimed that using the Internet to find resources for the teaching of reading (76.8\%) and for listening (73.2\%). Almost seventy-six percent also agreed that the Internet could be used to integrate the language skills. Using the Internet to find resources for the teaching of writing had the lowest level of agreement (58.9\%) amongst all the skills.

Table 6. Results related to language skills

\begin{tabular}{|l|c|c|c|c|}
\hline & $\begin{array}{c}\text { Strongly } \\
\text { Disagree } \\
\text { and } \\
\text { Disagree }\end{array}$ & Neutral & $\begin{array}{c}\text { Strongly } \\
\text { Agree and } \\
\text { Agree }\end{array}$ & \\
\hline & & $\%$ & Mean \\
\hline $\begin{array}{l}\text { 4. I especially use the Internet to find resources to } \\
\text { teach reading. }\end{array}$ & 3.6 & 19.6 & 76.8 & 4,0357 \\
\hline $\begin{array}{l}\text { 7. I especially use the Internet to find resources to } \\
\text { teach speaking. }\end{array}$ & 9.8 & 25 & 65.2 & 3,7411 \\
\hline $\begin{array}{l}\text { 11. The Internet is most useful for integrating skills. } \\
\text { 13. I especially use the Internet to find resources to }\end{array}$ & 5.4 & 18.8 & 75.9 & 4,0089 \\
\hline
\end{tabular}


teach listening.

16. I especially use the Internet to find resources to teach culture.

19. I especially use the Internet to find resources to teach vocabulary.

22. I especially use the Internet to find resources to teach writing.

26. I especially use the Internet to find resources to teach grammar.

\begin{tabular}{|l|l|l|l|l|}
\hline & 8.9 & 24.1 & 67 & 3,8482 \\
\hline & 2.7 & 15.2 & 82.1 & 4,0446 \\
\hline & 8.9 & 32.1 & 58.9 & 3,6964 \\
\hline
\end{tabular}

\section{Results Related to Web 2.0 Tools}

The questionnaire items shown in Table 7 concerned the Web 2.0 tools used by the participants. Almost eighty-five percent of the participants agreed that using Web 2.0 tools makes teaching more interesting and $82.1 \%$ claimed that using Web 2.0 tools increases student motivation. Results also show that $69.6 \%$ agreed upon using Web 2.0 tools while teaching the culture, while 28.6\% were not sure about it. Those who believed that the use of Web 2.0 tools increases cooperation among students make up $62.5 \%$ of the participants while $35.7 \%$ of them were not sure. This may indicate that some of the instructors are not fully aware of the functions of Web 2.0 tools that are conducive to cooperative learning.

Table 7. Results related to the use of Web 2.0 tools

\begin{tabular}{|l|c|c|c|c|}
\hline & $\begin{array}{c}\text { Strongly } \\
\text { Disagree } \\
\text { and } \\
\text { Disagree }\end{array}$ & Neutral & $\begin{array}{c}\text { Strongly } \\
\text { Agree } \\
\text { and } \\
\text { Agree }\end{array}$ & \\
\hline & \multicolumn{1}{|c|}{$\%$} & & Mean \\
\hline $\begin{array}{l}\text { 12. The use of Web } 2.0 \text { tools increases cooperation } \\
\text { among students. }\end{array}$ & 1.8 & 35.7 & 62.5 & 3,9018 \\
\hline $\begin{array}{l}\text { 15. Web 2.0 tools should be used to teach the target } \\
\text { culture. }\end{array}$ & 1.8 & 28.6 & 69.6 & 3,9018 \\
\hline $\begin{array}{l}\text { 17. Using Web 2.0 tools makes teaching more } \\
\text { interesting. }\end{array}$ & 0 & 15.2 & 84.8 & 4,2054 \\
\hline $\begin{array}{l}\text { 20. The use of Web } 2.0 \text { tools increases my students' } \\
\text { motivation. }\end{array}$ & 0 & 17.9 & 82.1 & 4,1607 \\
\hline
\end{tabular}

\section{Results Related to the use of blogs}

In the questionnaire' twenty-third, twenty-fourth, and twenty-fifth questions, the participants were asked about blogs. Of the participants, 59.8\% showed a positive attitude, and 33.9\% were neutral to the item "blogs should be used to teach reading". For the teaching of writing via blogs, $53.6 \%$ were positive and $41.1 \%$ were not sure, which shows that a considerable number of instructors do not have information about the role of blogs in teaching writing. Although over $50 \%$ of the participants agreed that blogs should be used to teach reading and writing, only $31.2 \%$ reported that they actually used blogs in their teaching.

Table 8. Results Related to the use of blogs

\begin{tabular}{|l|c|l|c|c|}
\hline & $\begin{array}{c}\text { Strongly } \\
\text { Disagree } \\
\text { and } \\
\text { Disagree }\end{array}$ & Neutral & $\begin{array}{c}\text { Strongly } \\
\text { Agree } \\
\text { and } \\
\text { Agree }\end{array}$ \\
& \multicolumn{2}{|c}{$\%$} & Mean \\
\hline
\end{tabular}




\begin{tabular}{|l|c|c|c|c|}
\hline 23. Blogs should be used to teach reading. & 6.3 & 33.9 & 59.8 & 3,7321 \\
\hline 24. I'm using blogs in my teaching. & 36.6 & 32.1 & 31.2 & 2,9464 \\
\hline 25. Blogs should be used to teach writing. & 5.4 & 41.1 & 53.6 & 3,6518 \\
\hline
\end{tabular}

\section{Results Related to the use of Podcasts}

Seventy-four point one percent of the participants agreed that podcasts should be used to teach listening and pronunciation. However, only $27.7 \%$ of the participants have previously recorded and uploaded a podcast. Furthermore, only $34.8 \%$ of participants actually used a podcast in their teaching. These results suggest that although the majority of the instructors think they know the benefits of podcasts, they do not use them while teaching.

Table 9. Results related to the use of podcasts

\begin{tabular}{|l|c|c|c|c|}
\hline & $\begin{array}{c}\text { Strongly } \\
\text { Disagree } \\
\text { and } \\
\text { Disagree }\end{array}$ & \begin{tabular}{c} 
Neutral \\
\multicolumn{1}{|l|}{}
\end{tabular} & $\begin{array}{c}\text { Strongly } \\
\text { Agree } \\
\text { and } \\
\text { Agree }\end{array}$ \\
\hline $\begin{array}{l}\text { 14. Podcasts should be used to teach listening and } \\
\text { pronunciation. }\end{array}$ & 0.9 & 25 & 74.1 & 3,9911 \\
\hline 27. I have recorded and uploaded a podcast before. & 51.8 & 20.5 & 27.7 & 2,6518 \\
\hline 28. I'm using podcasts in my teaching. & 38.4 & 26.8 & 34.8 & 2,9643 \\
\hline
\end{tabular}

\section{Results Related to Wikis}

Of the participants, $50.9 \%$ stated that wikis should be used to teach reading, and only $32.2 \%$ reported that wikis should be used to teach writing. Those that responded "neutral" were $43.8 \%$ for reading and $54.5 \%$ for writing. This can be interpreted as meaning almost half of the instructors are not sure about how wikis can be used in language teaching. Likewise, only $37.6 \%$ of the instructors indicated that they were using wikis in their teaching.

Table 10. Results related with the wikis

\begin{tabular}{|c|c|c|c|c|}
\hline & $\begin{array}{c}\text { Strongly } \\
\text { Disagree } \\
\text { and } \\
\text { Disagree }\end{array}$ & Neutral & $\begin{array}{c}\text { Strongly } \\
\text { Agree } \\
\text { and } \\
\text { Agree }\end{array}$ & \\
\hline & \multicolumn{3}{|c|}{$\%$} & Mean \\
\hline 29. Wikis should be used to teach reading. & 5.4 & 43.8 & 50.9 & 3,5625 \\
\hline 30. I'm using the wikis in my teaching. & 32.1 & 30.4 & 37.6 & 3,0357 \\
\hline 31. Wikis should be used to teach writing. & 13.4 & 54.5 & 32.2 & 3,2321 \\
\hline
\end{tabular}

\section{Results Relating to Social Networks}

Although $92 \%$ of instructors reported that they had an account on a social network site, just about half of them (49.1\%) stated that they were using social networks in their teaching. These results suggest that the use of social networks is quite popular among instructors, although they are not really used for teaching purposes. 
Table 11. Results related to social network sites

\begin{tabular}{|l|c|c|c|c|}
\hline & $\begin{array}{c}\text { Strongly } \\
\text { Disagree } \\
\text { and } \\
\text { Disagree }\end{array}$ & Neutral & $\begin{array}{c}\text { Strongly } \\
\text { Agree } \\
\text { and } \\
\text { Agree }\end{array}$ & \\
\hline 32. I have an account on a social network site. & 6.3 & 1.8 & 92 & 4,4643 \\
\hline 33. I'm using the social networks in my teaching. & 32.1 & 18.8 & 49.1 & 3,3036 \\
\hline
\end{tabular}

\section{Discussion and Conclusion}

This study aimed to determine the perceptions of EFL instructors towards the use of the Internet and Web 2.0 tools. It was conducted with the participation of 112 EFL instructors from various universities. The first research question aimed to find out how often EFL instructors use the Internet and Web 2.0 tools. The results showed that the tools most widely used by EFL instructors were search engines (3.46), e-mail (3.41) and social network sites (3.28). The least frequently used tools were podcasts (1.68), blogs (2.04) and wikis (2.27). These results indicate that EFL instructors do not use Web 2.0 tools as much as they use Web 1.0 tools.

In the second research question, the instructors were asked to state their level of proficiency in using the computer and the Internet. In this part, fourteen items were included and the participants specified for these items their proficiency. The summated mean was 3.77 which indicated that instructors had on the whole a high level of proficiency. The highest level of ability was in receiving and sending e-mail (4.79). The participants also indicated a high level of proficiency in using search engines, word processing, and presentation software, instant messaging and the downloading and storage of films/music. The participants' lowest level of proficiency was in SPSS (2.34) and in creating a web page on the WWW (2.46). When the results of the second research question are discussed together with the results of the first research question, it can be said that the instructors were employing e-mail and search engines the most frequently and that they also had a high level of proficiency in the use of these tools.

To find an answer to the third research question, the participants responded to 33 items concerning their perceptions of the use of the Internet and Web 2.0 tools for teaching. The summated mean for the participants' perceptions was 3.82, hence it can be concluded that they had quite a positive perception of the Internet and of Web 2.0 tools. According to these results, the instructors had a positive attitude towards Internet use and they stated that they used it in their classes. However they were not satisfied with the offered opportunities to learn about the Internet. The instructors agreed that Web 2.0 tools, namely blogs, podcasts, wikis and social networking sites should be used in the teaching of language skills but most of them stated that they were not using these tools in their teaching.

As a result, the current study showed that EFL instructors showed a positive attitude towards the use of the Internet and Web 2.0 tools in language teaching. However, they are not using these tools adequately in their teaching. 


\section{REFERENCES}

Al-Asmari A. M. (2005). The Use of the Internet among EFL Teachers at the Colleges of Technology in Saudi Arabia. Unpublished Doctoral Dissertation. Ohio State University. Ohio (U.S.A).

Al-Mekhlafi A. (2004). "The Internet and EFL Teaching: The Reactions of UAE Secondary School English Language Teachers". Journal of Language and Learning 2/2 (2004) 88-113.

Allen, M. (2008). "Promoting Critical Thinking Skills in Online Information Literacy Instruction Using a Constructivist Approach”. College \& Undergraduate Libraries 15 1/2 (2008) 21-38.

Arikan A. (2008a). "Prospective English Language Teachers' Foreign Language Skills and the Internet". Proceedings of E-Activity and Leading Technologies 2008, IASK - International Association for the Scientific Knowledge. Madrid, Spain.

Arikan A. (2008b). "Using Internet Groups in the Learning of Literature”. Hacettepe University Journal of Education. 34 (2008) 19-26.

Arkin E. (2003). Teachers' Attitudes towards Computer Technology Use in Vocabulary Instruction. Unpublished MA Dissertation. Bilkent University. Ankara 2003.

Cahyani H. \& Cahyono B. Y. (2012). "Teachers' Attitudes and Technology Use in Indonesian EFL Classrooms”. TEFLIN Journal: A publication on the teaching and learning of English 23/2 (2012) 130-148.

Caner M. (2009). A Study on Blended Learning Model for Teaching Practice Course in Pre-Service English Language Teacher Training Program. Unpublished Doctoral Dissertation. Anadolu University. Eskişehir 2009.

Cephe P. T. \& Balçıkanlı C. (2012). "Web 2.0 Tools in Language Learning: What Do Student Teachers Think?”. International Journal on New Trends in Education and Their Implications (IJONTE) 3/1 (2012) 1-12.

Dawley L. (2007). The Tools for Successful Online Teaching. Hershey, PA 2007.

Dogoriti E. (2010). "Perceptions and Attitudes towards Web-Based ELT among English Teachers in Greece". In International Conference "ICT for Language Learning.

Dovedan Z., Seljan S., \& Vučković K. (2002). "Multimedia in Foreign Language Learning”.. Proceedings of the 25th International Convention MIPRO (2002) 72-75.

Gilakjani A. P. \& Leong L. M. (2012). "EFL Teachers' Attitudes toward Using Computer Technology in English Language Teaching”. Theory and Practice in Language Studies 2/3 (2012) 630-636.

Hernández-Ramos P. (2004). "Web Logs and Online Discussions as Tools to Promote Reflective Practice”. The Journal of Interactive Online Learning, 3/1, 1-16.

Horzum M. B. (2010). "Investigating Teachers' Web 2.0 Tools Awareness, Frequency and Purposes of Usage in Terms of Different Variables”. International Journal of Human Sciences, 7/1, 604-634.

Lee L. (2005). "Using Web-Based Instruction to Promote Active Learning: Learners' Perspectives". Calico Journal 23/1 (2005) 139-156.

Kartal E. \& Arikan A. (2011). "Future Foreign Language Teachers and the Online Tools they Use to Learn about Foreign Languages, Literatures and Vultures". A paper presented at International eLearning Conference, 119-124. January 13-14, 2011. Impact Muang Thong Thani, Thailand.

Kassim H. \& Ali Z. (2007). "The Use of ICT in the Implementation of Student-Centered Learning (SCL)”. Internet Journal of e-Language Learning \& Teaching 4/1 (2007) 15-31.

Kavaliauskienè G. \& Anusienè L. (2009). "Podcasts for Listening Skills". Santalka. Filologija Edukologija 17/2 (2009) 28-37.

Khassawneh S. F. (2012). "EFL Teachers' Perceptions and Perspectives on the Use of the Internet in the Teaching Process at Yarmouk University in Jordan”. European Scientific Journal 8/13 (2012) 143155.

Kulekci G. (2009). "Assessing the Attitudes of Pre-Service English Teachers towards the Use of the Internet”. Journal of Kirsehir Education Faculty 10/3 (2009) 153-160.

Motteram G. \& Sharma P. (2009). "Blending Learning in a Web 2.0 World”. International Journal of Emerging Technologies \& Society 7/2 (2009) 83-96. 
Peachey N. (2009). Web 2.0 Tools for Teachers". Retrieved December 10, 2012 from http://www.technogogy.org.uk/Web20-Tools-for-Teachers.pdf.

Prensky M. (2001). "Digital Natives, Digital Immigrants”. On the Horizon 9/5 (2001) 1-6.

Rahimi M. \& Yadollahi S. (2011). "ICT Use in EFL Classes: a Focus on EFL Teachers' Characteristics”. World Journal of English Language 1/2 (2011) 17-28.

Rashtchi M. \& Hajihassani H. (2010). "Blog-Assisted Language Learning: A Possibility in Teaching Reading to Iranian EFL Learners”. International Journal of Language Studies (IJLS) 4/4 (2010) 245262.

Sahin-Kızl A. (2011). "EFL Teachers Attitudes towards Information and Communication Technologies (ICT)”. $5^{\text {th }}$ International Computer \& Instructional Technologies Symposium. Firat University. Elazı $\breve{g}$ 2011.

Saklavc1 A. (2010). The Use of the Internet among EFL Teachers at High Schools in Eskişehir. Unpublished Master's Thesis. Anadolu University. Eskişehir 2010.

Shin H. J. \& Son J. B. (2007). "EFL Teachers' Perceptions and Perspectives on Internet-Assisted Language Teaching”. Computer-Assisted Language Learning Electronic Journal (CALL-EJ) 8/2 (2007) 1-13.

Solmaz O. \& Bekleyen N. (2011). "The Use of the Internet by High School EFL Teachers for Professional Purposes”. Dicle Üniversitesi Sosyal Bilimler Enstitüsü Dergisi. Retrieved December 19, 2012 from http://e-dusbed.com/Makaleler/213372437_ID43\%20s.17-28.pdf

Usluel Y. K., Mazman S. G. \& Arikan A. (2009). "Prospective Teachers' Awareness of Collaborative Web 2.0 Tools”. Paper presented at the IADIS International Conference. WWW/Internet 2009, Rome, Italy. 